\title{
Katrina and the Thai Tsunami - Water Quality and Public Health Aspects Mitigation and Research Needs
}

\author{
A. J. Englande, Jr. ${ }^{{ }^{*}}$ \\ School of Public Health \& Tropical Medicine, Tulane University, New Orleans, LA 70112, USA \\ *Correspondence to Dr. A. J. Englande, Jr. E-mail: aenglan@tulane.edu
}

Received: 18 September 2008 / Accepted: 05 December 2008 / Published: 31 December 2008

\begin{abstract}
The South East Asian Tsunami in Thailand and Hurricane Katrina in the United States were natural disasters of different origin but of similar destruction and response. Both disasters exhibited synonymous health outcomes and similar structural damage from large surges of water, waves, and flooding. A systematic discussion and comparison of the disasters in Thailand and the Gulf Coast considers both calamities to be similar types of disaster in different coastal locations. Thus valuable comparisons can be made for improvements in response, preparedness and mitigation. Research needs are discussed and recommendations made regarding potential methologies. Recommendations are made to: (1) improve disaster response time in terms of needs assessments for public health and environmental data collection; (2) develop an access-oriented data sharing policy; and (3) prioritize natural geomorphic structures such as barrier islands, mangroves, and wetlands to help reduce the scale of future natural disasters. Based on the experiences gained opportunities to enhance disaster preparedness through research are presented.
\end{abstract}

Keywords: Hurricane Katrina, tsunami, disaster preparedness, research needs, and lessons learned

\section{Introduction}

On December 26, 2004 at 7:58 in the morning, an undersea earthquake west of Sumatra Island in Indonesia initiated a strong tsunami first hitting nearby beaches with the most intense force, then other countries including India, Malaysia, Maldives, Myanmar, Somalia, Sri Lanka, and Thailand. The waves in Thailand were first reported on the Phuket Province coastline at 9:38am; when, threemeter high tidal waves hit the shore followed fifteen minutes later by a three to ten meter giant wall of water which extended for several kilometers pushing floodwaters up to one kilometer inland. A third series of five-meter-high waves followed the water wall [1]. This was one of the most deadly natural disasters in modern history with a total estimated 229,866 persons lost, including 186,983 verified as dead and 42,883 missing. In Thailand, 8,212 people were verified dead or missing with over 2,448 of those as non-Thai from thirty-six different countries [2]. Losses in Thailand were estimated at 1.6 billion U.S. dollars with a minimum repair cost of 482 million US dollars.

Nine months after the tsunami in Asia, Hurricane Katrina made landfall on the U.S. Gulf Coast on August 29, 2005 at 6:10 am. The disaster was characterized by heavy rains, a devastating storm surge up to ten meters high in Mississippi, and strong winds reported at a maximum of $215 \mathrm{kph}$ near Buras, Louisiana. The storm surge's wall of water caused wide-spread tidal damage to coastal areas to all Gulf Coast states with many areas in Mississippi and Louisiana completely destroyed. It also induced breeches in the New Orleans levee system, flooding $80 \%$ of the city, limiting government access and isolating many families and individuals, many in poor health status, without any electricity, food, or drinking water [3]. The remaining population of the New Orleans metropolitan area had to live multiple days in a harsh urban landscape where little was known about security, safety of the ubiquitous floodwater, 
or the future in general. The immediate destruction, flooding, and related issues accounted for over 1,800 deaths in all affected areas with about 1,600 in Louisiana and 240 in Mississippi [4, 5]. The total damage from Katrina was over 125 billion US dollars.

\section{Scope and Objectives}

The S.E. Asian Tsunami in Thailand and Hurricane Katrina in the U.S. were natural disasters of different origin but of similar destruction and response. Both disasters exhibited synonymous health outcomes, similar population targets including low socioeconomic status groups, and similar structural damage from large surges of water and waves. These events afford great learning opportunities for better preparedness for future disasters and a need of improved, coherent public health response and resource prioritization. By considering both calamities to be similar types of disasters in different coastal locations, valuable comparisons can be made for improvements in response and preparedness. Pertinent responsive research is needed as well as remediation technology development and implementation. It is suggested that other coastal areas in the world heed the advice and lessons learned and be proactive by developing plans in anticipation of the next disaster rather than responding after the fact.

This paper discusses both the Thailand Tsunami and the Louisiana/Mississippi Hurricane Katrina in reference to environmental health planning before the disaster, the environmental health impacts, and future planning, research needs and mitigation needs in expectation of a similar event in comparable locations. Emphasis is given to water and environmental health. Recommended actions and research needs are provided to improve response to future disasters in similar coastal areas.

\section{Results and Discussion}

\section{Pre-Storm Thailand, the New Orleans Metropolitan Area and the Mississippi Gulf Coast}

\section{Pre-Storm Thailand}

The areas affected by the tsunami in Thailand included many tourist beach resorts on the water front. A few national forests, a number of mangrove areas, and some undeveloped areas were also hit by the tsunami. Behind the tourist resorts, there was a variety of housing ranging from middle class villas, to temporary squatter huts built by migrant Myanmar workers and nomadic Thai Moken fishermen. Many of the poor communities around the tourist resorts or shrimp farms had pre-existing disease burdens of acute respiratory illness or chronic diarrhea, both characteristic of global poverty.

Disaster plans existed among government agencies and hospitals. They were regularly rehearsed for general types of disasters, most likely mass causalities associated with the many isolated terrorist threats in the southern provinces. Being quick in emergency response and post-impact recovery, these plans were applauded by many international observers. The plans lacked longer term preparedness and mitigation from natural disasters but efforts by the royal family before the disaster emphasized the protection of coral and mangroves for ecological purposes, and unknowingly, natural defensive justifications [6].

\section{Pre-Storm New Orleans}

In August, 2005 metropolitan New Orleans and surrounding areas were served by five large scale waste treatment facilities and sewerage systems. The East Bank of the city is serviced by centralized water and sewerage treatment plants treating approximately 500,000 $\mathrm{m}^{3} /$ day and $375,000 \mathrm{~m}^{3} / \mathrm{d}$, respectively. As the city is built on elevations sometimes lower than the surrounding lake or river, the separate storm water is pumped into Lake Pontchartrain during and following a rain event. The sewerage system and drinking water distribution systems were in need of repair and the city at the time was implementing a one billion dollar capital improvement program in response.

Much of the city's development occurred on land previously wetland or marsh. Hence the city depends on levees for flood/ hurricane protection. Much of the natural protection of wetlands has been significantly reduced by both man and natural activities. Approximately 475 million dollars have been spent through the Breaux Act on over 107 restoration projects. Even with these, Louisiana continues to lose its wetlands at a rate of about 0.4 hac every 24 minutes.

\section{Pre-Storm Mississippi}

In August 2005, the Gulf Coast area of Mississippi was served by 126 wastewater treatment facilities approaching overload conditions from significant population increases due to rapidly developing subdivisions and casino development. Water treatment facilities numbered about 200 and were generally small with only seven servicing more than 10,000 people.

The State of Mississippi had an effective early warning system and hurricane evacuation routes, and special needs population plans set up, but other logistics such as shelter locations, volunteer management, and response to potential hazardous waste contamination from industrial facilities was limited.

\section{Disaster Impacts}

A summary of general disaster impacts and environmental impacts are presented in Tables 1 and 2 respectively. These are discussed in the following. A more detailed discussion can be found in an article by Englande et. al. [7]. Figure 1 shows selected photos of destruction caused bt the Thai tsunami and hurricane Katrina. 
Table 1: A Summary of General Disaster Impact Areas

\begin{tabular}{|c|c|c|c|}
\hline Impact & Thailand & New Orleans Areas & Mississippi Gulf Coast \\
\hline Damage & $\begin{array}{c}\text { Tsunami } \\
\text { (10 meter waves) }\end{array}$ & Levee overtopping/breaching-standing water & Hurricane surge (10 meter) \\
\hline $\begin{array}{l}\text { Needs Assessments } \\
\text { CDC/MMWR }\end{array}$ & $\begin{array}{c}\text { Rapid } \\
\text { (12 days and sooner) }\end{array}$ & $\begin{array}{c}\text { Slow } \\
\text { (46 days) }\end{array}$ & $\begin{array}{l}\text { Moderate } \\
\text { (18 days) }\end{array}$ \\
\hline Health & $\begin{array}{c}\text { Some Diarrhea } \\
\text { Isolated Vibrio vulnificus } \\
\text { and Aeromonas spp. }\end{array}$ & \multicolumn{2}{|c|}{ Some cases of Vibrio vulnificus and parahaemolyticus reported } \\
\hline $\begin{array}{l}\text { Environmental Data } \\
\text { Collection }\end{array}$ & $\begin{array}{l}\text { Government groups: Not } \\
\text { made public }\end{array}$ & $\begin{array}{l}\text { Various groups: Not immediately available } \\
\text { to public. Varying interpretation }\end{array}$ & $\begin{array}{r}\text { EPA, MSDEQ, MSDH and } \\
\text { others. Immediately } \\
\text { available. }\end{array}$ \\
\hline
\end{tabular}

Table 2: General Disaster Impact Areas - Environmental Issues

Thailand New Orleans Areas Mississippi Gulf Coast

Wells/ reservoirs contaminated with Central water and wastewater facilities salt water, sediment and animal/human corpses impaired. FEMA taskforce assigned to mitigate issues
26 wastewater facilities affected infrastructure, electrical problems

Six weeks after storm all water / wastewater facilities operational

Imported water; dual supply membrane treatment for drinking water / food preparation

Water treatment impaired. Boil water alert

Super-chlorination.

Low water pressure

Population relocated to temporary camps

Mold not an issue; mosquito larvicide spraying
Mold problems; mosquito larvicide spraying

Debris collection / disposal concerns
Water treatment impaired. Boil water alert Imported water Membrane treatment

Well testing / disinfection by MSDH; EPA / FLA mobile labs

Mold concerns less than NOLA; mosquito larvicide spraying

Debris collection disposal concerns 

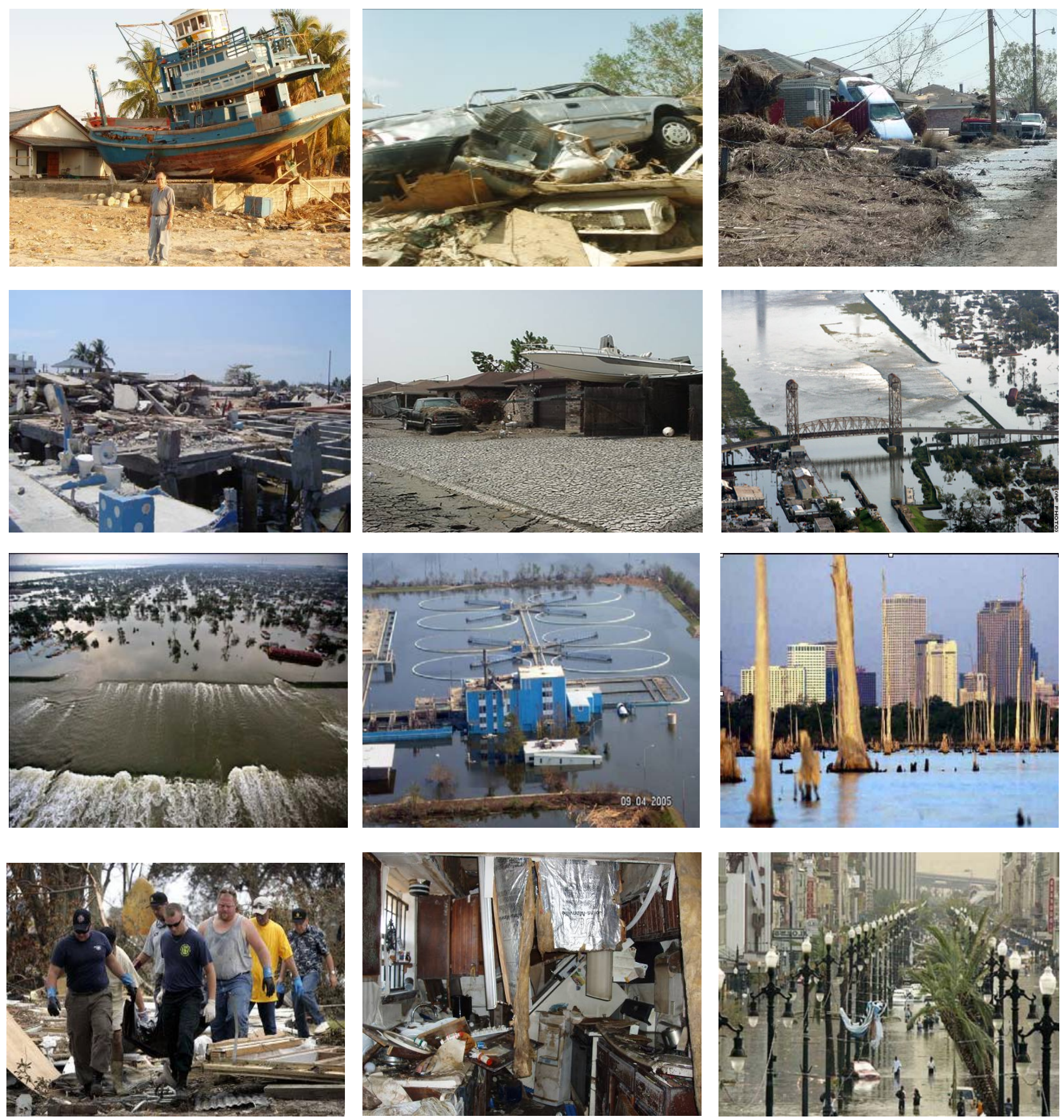

Figure 1: Selected photos of hurricane Katrina in the Gulf Coast areas of the United States of America 


\section{Storm Impact Thailand}

The Thai Ministry of Public Health responded rapidly to the tsunami disaster through organizing clinicians, medical supplies, treatment of injuries, burying, and identification of the dead. A large number of enteric pathogens were cultured from wounds which suggested surface contamination with organisms cultured as $A$. hydrophila and Vibrio vulnificus, similar to some polymicrobial infections detected during hurricane Katrina [8]. The Thai relief efforts were complemented by foreign governments such as the United States Center for Disease Control (CDC) collaboration, the government of Germany, and many others, but the Thais maintained that most programming of the disaster response was organized by the government itself [9] through its central command in Bangkok with command centers in each of the six impacted provinces. Tulane University faculty, students, and Thai alumni coordinated with the Pollution Control Department (PCD) and a provincial health department to conduct a needs assessment on environment related issues.

Environmental health data was collected by the Pollution Control Department (PCD) but not made public in the months after the disaster. Because flooding associated with the Tsunami drained quickly away from affected areas, the environmental data focused on wells and surface water bodies. In addition to environmental parameter testing, government officials and the public were quick to declare most surface water unsuitable for drinking or treatment if rumors suggested that a human or animal corpse was in the water. Fortunately, drinking and bathing water were readily available from well-stocked government supplies and many natural springs from nearby mountains. Additionally a system of dual water supply was enacted using uncontaminated reservoir or mountain spring water, depending on location. A membrane technology was used for drinking and food preparation and stored and labeled at a central location in each temporary camp; while, untreated source water was also stored and labeled to be used for other purposes.

\section{Storm Impact New Orleans}

The first needs assessment was conducted by the CDC approximately seven weeks after the hurricane. Many residents in Orleans Parish were still without basic utilities and services such as running water, electricity, and garbage and debris removal. A needs assessment determined some of the residents and relief workers in the New Orleans area had diarrhea (3.5\%), acute respiratory infections (12.1\%), and skin or wound infections (15.4\%). It was also determined that almost half (49.8\%) of the adult residents in the New Orleans area exhibited levels of emotional distress indicating a need for mental health services, while over half of the households (55.7\%) had a member with chronic health conditions [3].

Data collection during the Katrina disaster was organized by various groups. Although much data was not made immediately available due to copyright concerns of researchers and data processing time, many data summaries were later available on the internet. These data have been discussed with varying interpretations.

Although the news media claimed the flood waters were a "toxic soup", researchers reported the waters as comparable to typical storm water. An absence of major toxic affects in the flood waters were due to dilution, an absence of refineries or chemical plants in the levied areas of New Orleans, gasoline stations in short supply, and the strong alkalinity in the flood waters buffering the potential acidic effects of the many submerged car batteries [10].

The infamous aid response to New Orleans Katrina disaster is known through the news media globally. Although wind damage and flooding due to rain occurred in the New Orleans area, the flooding due to levee breaks introduced a different sort of destruction than that seen in Mississippi or the Thai tsunami. Over $80 \%$ of the city's homes and buildings were flooded and access was a major issue for stranded residents and emergency workers.

All of the major wastewater and drinking water treatment plants around New Orleans were impacted by flooding, wind damage, electrical problems, or other associated issues. In the eastbank wastewater treatment plant, the surrounding waters rose to levels above the facility's earthen levees. A Federal Emergency Management Agency (FEMA) task force was assigned to mitigate these issues and within six-nine weeks, many of the areas facilities were back online [11]. Since the hurricane, the NOSWB had to double the pumping capacity of drinking water and increase the chlorine dose to super-chlorination levels which increased consumer concern over taste and odors and disinfection byproducts. Low water pressure handicapped fire fighting activities. Another major environmental concern after the storm was huge piles of debris, and its removal as nearby landfills approached their limits.

\section{Storm Impact Mississippi}

All of the twenty-six wastewater facilities in Mississippi counties severely affected by Hurricane Katrina were damaged with many infrastructure and electrical problems Thousands of on-site treatment facilities, particularly above ground systems, were also damaged. Similarly, most water treatment facilities and distributions systems sustained significant infrastructure damage. This prompted a blanket boil water alert for all six coastal counties.

On September $14^{\text {th }}$ a rapid community Needs Assessment was conducted. This was conducted over one month before the New Orleans rapid Needs Assessment. Because the flood waters quickly receded, access in most cases, was not as serious of an issue as it was in New Orleans. Federal, state, and volunteer emergency services were quick to arrive, coordinate and provide relief with minimal turf issues as evidenced in other areas.

Thirty thousand FEMA mobile homes and recreational vehicles (RVs) were placed in the affected area with localized wastewater treatment at each park. 
Private drinking water wells were utilized, but mostly bottled drinking water was transported to the sites in the early weeks following the hurricane. By six weeks following the storm, $85 \%$ of drinking water facilities and $95 \%$ of wastewater facilities in Louisiana and Mississippi were operational. Boil water recommendation remained in effect until all treatment plants could be tested [12]. Some membrane treatment systems were used for desalinization of drinking water; while, in rural areas the State Department of Health initiated a program for individual well testing and instruction to owners for disinfection and sampling of their private wells. Various other government agencies and state groups assisted in the testing and EPA's RMP (Risk Management Plan), Tier II, TRI (Toxic Release Inventory) for various contaminants of concern. The data and summaries were made available on the EPA website [13].

\section{Response and Lessons Learned}

\section{Thailand}

The most urgent problem which faced the Thai Ministry of Natural Resources after the tsunami was spread of contamination from "seawater, wastewater, mud, sand and decomposing bodies" [14]. Although these may not have had as serious of pathogenic consequences as originally assumed, the Thais did prioritize these issues and minimized them in only a few weeks during the time following the disaster.

To mitigate and prepare for another tsunami, the Thai government released official reports from the Ministry of Natural Resources and Environment to prioritize marine and coastal ecology efforts including mandates to further protect, enhance, acknowledge, and beautify the naturally occurring coral, sea grass beds, and mangrove forests. The ministry also recommended more eco-tourism promotion, more natural resources for drinking water such as artesian wells, and coordinated work with local communities to fulfill these tasks [1]. Lastly, an early warning system was stressed where the Thai can have up to an hour's warning for complete evacuation. This system indicating sudden rise in sea level is currently in place for the Andaman Sea.

\section{Current and Future Solutions - New Orleans}

The mayor's "Bring New Orleans Back" [15] plan (health and social services committee) included priorities towards recovery and included recommendations to reduce vulnerability through improving resiliency in health status, databases, and disaster response. The recommendations acknowledge that many contaminant levels in the city were similar to background levels before the storm, while some parameters such as lead and arsenic were found in excess of EPA recommended levels. It also acknowledged that there were many conflicting interpretations to similar data and findings available from groups; and, there was a need to have government representatives as specialists in risk communication to decipher available data. Most importantly, the report emphasizes expedient release of scientific data to all stakeholders.

The report recommended a need to: identify data gaps; assess the health risk of mold; assess the soil, sediment, and surface water samples for bacterial contamination and chemical compounds; and stressed that data be released to all stakeholders with culturally sensitive interpretations to be utilized by policy makers who consider science and other social/economic issues.

Following Hurricane Katrina, the New Orleans Sewerage and Water Board ran a deficit of $\$ 80,000$ per day due to drinking water distribution system leakage. The city had to pump more than twice as much drinking water into the system to keep the water pressure high to reach all customers. The large amount of underground flooding also necessitates super chlorination which resulted in public complaints due to odor and taste, in addition to potential disinfection byproduct concern.

To address the major Katrina problems associated with storm drainage, drinking water and wastewater treatment facilities in the New Orleans area, the Federal Emergency Management Association (FEMA) formed a task force with various local and national government groups to provide comprehensive engineering restoration/repair. The group was able to re-start two wastewater facilities and one drinking water facility in the metropolitan area within six to nine weeks following Katrina which is regarded as one of the most challenging and successful engineering feats in New Orleans history.

\section{Current and Future Solutions - Mississippi}

The Mississippi Department of Health (MDH) coordinated with the MS Department of Environmental Quality and the EPA for evaluations of rural and FEMA trailer park wastewater treatment and drinking water supplies (over 35,000 FEMA trailers were deployed). The state received a 500 million dollar grant from the U.S. Housing and Urban Development (HUD) to improve drinking water supply and sewerage infrastructure in the six affected MS counties [16]. The Gulf Coast Regional Infrastructure Program is developing areas where: (1) many of the displaced population have moved which do not have adequate water, wastewater, and storm water infrastructure; and (2) where existing infrastructure had been damaged by the storm.

Many homeowners have moved to developing rural areas farther away from the coastline. The public health infrastructure has also adapted by shifting to new developed areas and moving vital health data to a central location in Jackson [17].

\section{Assessment}

Overall, the cost of the tsunami in Thailand was estimated at 1.6 billion US dollars, while Hurricane Katrina's cost was over 125 billion US dollars across the 
Gulf Coast. The trend is reversed for mortality; Thailand had over 8,200 fatalities while more than 1,800 occurred in the New Orleans/Gulf Coast areas. The difference is due to the lack of an early warning system in Thailand which has since been rectified.

\section{Health}

The largest health similarity amongst the disasters is that most deaths were due to drowning across all income levels. However, the loss of life during Katrina approaches the scale of what may be expected in developing countries. In both cases many fatalities were among the elderly and poor. These communities are often marginalized by lack of transport, education, and poor housing locations.

New studies in Thailand report that the opportunistic Aeromonas spp. was isolated from $22.6 \%$ of infected wounds following the tsunami [18]. Although largely unstudied in Katrina, these bacteria represent an emerging global health threat [19] and were found in many of the flood waters. Some human cases were also reported [8]. It is assumed that poor hygiene and drinking water contributed to the elevated diarrhea problem in Thailand; diarrhea was measured in the New Orleans needs assessment (3.5\%), but it is not clear if this is above endemic levels. Cases of Vibrio vulnificus and $V$. parahaemolyticus were reported with six deaths. For both disasters, no significant disease outbreaks grew beyond expected levels.

\section{Structural Damage}

Wind and rainfall-induced flooding typically account for the majority of damage during a hurricane, but the storm surge associated with Katrina produced effects which resembled the 2004 Thailand tsunami. Structural damage in both areas was due to a huge wall of water, sometimes thirty feet high in areas of Thailand and the Gulf Coast. In both Thailand and the Gulf Coast, engineered structures suffered similar types of damages through hydrostatic and hydrodynamic loads- both lateral and vertical - debris impact and damming loads, and scour of supporting soil. This storm surge had a different effect in New Orleans where only the Ninth Ward and St. Bernard Parish's Arabi/Chalmette neighborhoods reported surges of water. Most flooding in New Orleans was caused by levee failures and subsequent rising waters which remained in place for two to three weeks. Wind damage was also significant in all areas affected by the hurricane [20].

\section{Environmental Damage}

Many areas in Thailand had thick mangrove systems extending for at least several hundred meters on land. Communities located behind these forests were often protected from the tsunami. The story was different in Sri Lanka where many Mangroves and other vegetation had been cut down, leaving only a thin weakly-protective layer of vegetation near the beach front; whereas, the fatalities from the tsunami were much more $[21,22]$.

After the tsunami, the wave buffering effect by coral was witnessed in many countries; the Maldives and Thailand found that their policies of coral protection for ecological reasons had also served as coastal protection from the tsunami [23, 24].

In Thailand, the conservation of mangroves translates to less production of one of its largest exports- shrimp farming. However, the royal family recognized these issues around mangroves and healthy coral and implemented strategies to mitigate mangrove destruction and also provide alternative livelihoods for shrimp farmers prior to the tsunami [6]. Like most disasters, the tsunami prioritized the need for natural defenses; the government is now allocating more land for mangroves and allowing only a few of the impacted and displaced shrimp farmers to return.

Similar to how mangrove and coral acted as protective defenses against the tsunami, wetlands and barrier islands are the U.S. Gulf Coast's natural defenses. Unfortunately, these have been significantly degraded over the years. Since the 1930s coastal Louisiana has lost over 900,000 acres of coastal wetlands with a current a rate of 16,000 acres per year; where, $70 \%$ of this loss in coastal wetlands derives directly or indirectly from human activity [25].

A positive outcome from both disasters is that awareness of the issue has now increased many-fold among the lay population in Thailand and the U.S. Gulf Coast with a hopeful renewed emphasis in government and donor budgets.

\section{Water and Wastewater}

With most water and waste water treatment systems suffering damages during the flooding and storm surge associated with Katrina, recovery of these facilities took more than six weeks before functionality was restored. In Thailand, the few local drinking water treatment facilities which sustained damages were restarted within a similar time frame. Some were not repaired due to relocation of communities. Greater flexibility and reduced vulnerability were demonstrated by decentralized water and wastewater systems for both disasters.

\section{Other Environmental Health Concerns}

Mold is the single most extensive environmental health issue in the Gulf Coast area. Most buildings in New Orleans rely on air conditioners for ventilation and prevention of mold growth during the hot season. Traditional Thai houses and communities are naturally adapted to mold and most use a building style with much ventilation, light, and few dark spaces. Mold was a concern more in the New Orleans area since most water did not drain away until weeks after the storm. 
Mud, sediment, and debris were major environmental health concerns in the Katrina disaster. During the Thai tsunami, the government relocated families to military run shelters which did not suffer from this type of problem. The Thai infrastructure destruction situation, in general, was much smaller in magnitude than the Katrina disaster and much of the debris was gone only a few months after the tsunami.

\section{Data Sharing}

In the Asian tsunami and the Katrina disasters, rapid data and other relevant information were collected by various groups including local and national government health/environment authorities, relief agencies, and academic groups. These emergency fact-finding expeditions were often given great priority for appropriate response to evidenced needs, but too often the data was shared only internally. In the immediate weeks and months following both the tsunami and Katrina, release or interpretation of collected environmental data was problematic. A frequently updated publicly accessible, searchable, and comprehensive database is needed to disseminate information to avoid duplication of efforts and avoid bad decisions in emergency contexts which are often resource limited [26].

\section{Recommendations and Needs}

Based on the foregoing the following recommendations and needs are summarized.

- Emphasis needed on natural protection in coastal areas such as wetlands, barrier islands, "horizontal levees" etc.

- $\quad$ Need integrated system with levees, wetlands, storm buffering environments

- Need for enhanced communications including network connecting needs with suppliers

- $\quad$ Need for better coordination of volunteer groups to avoid duplication (volunteer reference center)

- Better use of community based organizations especially for risk communication and other outreach efforts

- $\quad$ Need for redundancy in design and consideration of decentralized water and wastewater treatment facilities

- Timely public disclosure of environmental media sampling results by websites, newspapers, radios and postings.

- Coherent and agreeable interpretations of environmental data by an organization of recognized specialists - such as organized at Tulane by KERRN www.kerrn.org - an organization linking professionals, government, and concerned citizens together in the aftermath of the Katrina or future disasters

- $\quad$ Need for better exposure models; mold standards.
- $\quad$ Need for improving public health and medical support during crisis and precrisis planning for special needs populations

- Plans to handle environmental health, social services, increased trauma, depression, abuse, suicide, violence

- $\quad$ Need for long term planning of land use and security issues

- $\quad$ Need for political will and public support

- $\quad$ Need for more sustainable approaches

- Need for getting the right science to the right people for policy changes

\section{Research and Education Needs}

From the experiences gained from the two disasters as discussed herein opportunities exist to enhance disaster preparedness. Some of the potential research topics include:

- Integrated environmental information technology to support decision making and disaster management:

- Real-time communication, information access, environmental monitoring and data interpretation pre, during and post event

- Frequently updated, publicly accessible, searchable and comprehensive GIS data base to disseminate information

- Enhance communication for potable water/wastewater systems status and needs

- Risk assessment/risk communication:

- $\quad$ Better human health risk assessment methods for short-term exposure of highly toxic concentrations using different disaster scenarios

- $\quad$ Better exposure models and standards (ex. Mold)

- Microbial risk assessment approaches for various scenarios

- Environmental hazard tracking: 1)amount and distribution of contaminants 2) exposure 3) health outcome tracking

- Methodologies to disseminate disaster risk messages and other essential information for risk communication

- Enhancement of public health and quality of urban water during and after extreme events to provide safe water for water supply and sanitation:

- Integrated, onsite decentralized water and wastewater systems for use during and post disaster-events

- $\quad$ Spread sheeting and color-coded GIS mapping to track systems status, contact info and needs including boil water alerts

- $\quad$ Effective decision making guidelines:

- Use of formal decision modeling to assess multiobjectives, attributes and stakeholders in disaster management and recover decisions

- Cross-disciplinary curriculum development for students to acquire skills needed for disaster management and pertinent research 
- Methodologies to translate research findings into commercial applications and products.

\section{Conclusions}

Although the two disasters were different in type, scale, and destruction, the Thai government's response appears more efficient than what occurred in New Orleans. However, the scale of the affected area in Hurricane Katrina (the size of the UK) was much larger than the land affected in Thailand and the two governments, cultures, living standards, and political systems are much different. The biggest difference being that New Orleans/Gulf Coast had an early warning system of the disaster to come while Thailand did not. The response of the New Orleans/Mississippi areas was slower. Quick decisive action by the Thai military and Public Health and other public utilities had little political boundaries to administer aid. There was little room for political bickering and turf battles in the authoritarian disaster zone after the tsunami. The Mississippi response was also uniquely different from the New Orleans area response. The state is known for offering more coordination and participation with federal government aid groups, but the situation was also much different as standing water was not a major issue. It is suggested that other coastal areas in the world heed the advice and lessons learned and be proactive by developing plans, structures, and societal changes in anticipation of the next disaster rather than responding after the fact. Responsive research and mitigation projects are needed to better prepare for future disasters.

Acknowledgements: The support and logistics planning of Luksamee Promakasikorn and the Pollution Control Department of Thailand, the Faculty of Maihdol University School of Public Health, the Provincial Health Department and Hospitals in Phuket and Phang Nga provinces, Thailand and the Tulane University School of Public Health and Tropical Medicine are gratefully acknowledged.

\section{References}

1. Sinthuvanich, D.; Boonprakub, S.: Rehabilitation Actions Taken. Bangkok Thailand:Office of Natural Resources and Environmental Policy and Planning Ministry of Natural Resources and Environment: http://www.onep.go.th/download/1y after_tsunami/in dex.html [accessed June 2006].

2. UN. 2005. United Nations Office of the Special Envoy for Tsunami Recovery Website. New York: http://www.tsunamispecialenvoy.org/default.aspx [accessed June 2006].

3. Daley, W.: Public Health Response to Hurricanes Katrina and Rita--United States, 2005. Morbidity Mortality Weekly Report. 2006, 55(9), 229-231.

4. Franklin, M. Columbia geophysicist wants 'full' Katrina death toll. Associated Press (New York). October 28, 2006.
5. LDHH. Hurricane Katrina: reports of missing and deceased.

http://www.dhh.louisiana.gov/offices/page.asp?ID=19 2\&Detail=5248 [accessed October 2006].

6. Weerapong, D. 2004: New site for nature lovers in Bangkok. Bangkok, Thailand:World Wildlife Foundation Newsletter. http://www.panda.org/ about_wwf/what_we do/marine/news/successes/inde x.cfm?uNewsID=14713 [accessed June 2006].

7. Englande, A.; Sinclair, R.; Lo, P.: Water Quality and Public Health- Case Studies of Hurricane Katrina and the December 2004 Tsunami in Thailand. Cities of the Future. Novotny, V. and Brown, P. (eds.). IWA Publishing, London. 2007, pp.52-71.

8. Engelthaler, D.; Lewis, K.; Anderson, S.; Snow, S.; Gladden, L.; Hammond, R., et al.: Vibrio illnesses after Hurricane Katrina--multiple states. Morbidity Mortality Weekly Report. 2005, 54(37), 928-931.

9. Prabahorn, L.: Personal communication on public health response of government to tsunami. Englande AJ, Sinclair RG, eds. August-September, 2005.

10. Pardue, J. H.; Moe, W. M.; McInnis, D.; Thibodeaux, L. J.; Valsaraj, K.T.; Maciasz, E., et al.: Chemical and microbiological parameters in New Orleans floodwater following Hurricane Katrina. Environmental Science and Technology. 2005, 39(22), 8591-8599.

11. Bankston W.: FEMA public assistance: Katrina - an inside look at the recovery efforts. Power Point Presentation. Harahan. FEMA, Area Field Office. 2006.

12. Copeland C. Hurricane-Damaged Drinking Water and Wastewater Facilities: Impacts, Needs, and Response. Congressional Research Service: The Library of Congress. Available: www.ncseonline.org/nle/ crsreports/05oct/RS22285.pdf [accessed June 2006].

13. USEPA. Environmental Assessment Summary for Areas of Jefferson, Orleans, St. Bernard, and Plaquemines Parishes Flooded as a Result of Hurricane Katrina. Environmental Protection Agency Response to 2005 Hurricanes. 2005. http://www.epa.gov/katrina/testresults/katrina_env_as sessment_summary.htm

14. Sinthuvanich, D.; Boonprakub, S.: Unified Assisstance to Affected Areas. Bangkok, Thailand:Ministry of Natural Resources and Environment: The Office of Natural Resources and Environmental Policy and Planning. 2005. http://www.onep.go.th/download/1y_after_tsunami/ index.html [accessed June 2006].

15. Health and Social Services Committee. New Orleans. Bring New Orleans Back Plan: 2006

16. Spengler, S.: Gulf Coast Regional Infrastructure Program Report. Mississippi Development Authority. Available:www.deq.state.ms.us. [Accessed June 2006].

17. Mississippi's Part C State Performance Plan 20052010: First Steps. Mississippi Department of Health: Office of Health Services: Bureau of Child and Adolescent Health: Early Intervention Division. 
MDH. http://www.msdh.state.ms.us/msdhsite/_static/ resources/1565.pdf [accessed June 2006].

18. Hiransuthikul, N.; Tantisiriwat, W.; Lertutsahakul, K.; Vibhagool, A.; Boonma, P.: Skin and Soft-tissue Infections among Tsunami Survivors in Southern Thailand. Clinical Infectious Diseases. 2005, 41, 9396.

19. Presley, S. M.; Rainwater, T. R.; Austin, G. P.; Platt, S. G.; Zak, J. C.; Cobb, G. P.: Assessment of Pathogens and Toxicants in New Orleans, LA Following Hurricane Katrina. Environmental Science and Technology. 2006, 40, 468-474.

20. Pace, D. National Trust to survey Gulf Coast historic buildings. Associated Press. September 15, 2005.

21. Kathiresan, K., Rajendran, N. Coastal mangrove forests mitigated tsunami. Estuarine, Coastal and
Shelf Science. 2005, 65(3), 601-606.

22. Wabnitz, C.; Alder, J.; Change, S.: A tale of two landscapes. British Columbia,UBC. 2005, http://www.fisheries.ubc.ca/publications/fishbytes/.

23. Coral Reefs and Mangroves May Have Helped Saved Lives in Tsunami Area. IEMA. 2005. Available: http://www.iema.net/news/envnews?aid=4972

24. WWF Issues. Tsunami Paper. Available: 2005. http://www.iema.net/news/envnews?aid=4974 .

25. Galloway, G. America's WETLAND: Campaign to Save Coastal Louisiana. New Orleans, Louisiana. 2003. http://www.lacoast.gov/news/press/2004-0413/report27Jan042.pdf .

26. Mills, E. J.; Robinson, J.; Attaran, A.; Clarke, M.; Singh, S.; Upshur, R. E.: Sharing evidence on humanitarian relief. British Medical Journal. 2005, 331(7531), 1485-1486. 